\section{Lychee Pericarp Browning Caused by Heat Injury}

\author{
S.J.R. Underhill and C. Critchley ${ }^{1}$ \\ Horticulture Postharvest Group, Queensland Department of Primary Industries, \\ 19 Hercules Street, Hamilton, Queensland 4007, Australia
}

Additional index words. Litchi chinensis, polyphenol oxidase, catechol oxidase

Abstract. Mature lychee (Litchi chinensis Sonn.) fruit were heat-treated at $60 \mathrm{C}$ for $10 \mathrm{~min}$ to study heat-induced pericarp browning. Polyphenol oxidase (EC 1.10.3.2) activity of the pericarp increased immediately, corresponding with rapid anthocyanin degradation, Tissue browning was observed 2 min after heating, with pigmentation distributed uniformly throughout the pericarp. The distribution of brown pigments was different than the highly localized browning observed under ambient desiccation. Although both ambient and heat-induced pericarp browning are visually similar, the anatomical distribution of brown pigmentation is quite distinct. The distribution of brown pigmentation was not consistent with anthocyanin localization. Following ambient desiccation, the mesocarp became colorless even though this represented the greatest concentration of pigment. Browning caused by heating may result from nonselective degradation of a range of compounds, including anthocyanin.

Lychee pericarp browning is a general surface injury commonly observed after harvest (Nip, 1988). Injury is known to occur in response to a wide range of factors, including climatic conditions during ontogeny (Sharma et al., 1986), fungal infection (Huang and Scott, 1985), desiccation (Scott et al., 1982), fruit senescence (Huang et al., 1990), and heat injury (Wong et al., 1991). Once present, it is difficult to identify the initial stress that caused the injury. As a result of this seemingly uniform injury, lychee pericarp browning has been studied as a single degradation system, with little emphasis placed on the original stress. Most previous studies have involved browning from postharvest desiccation. Relatively little is known about injury mechanisms under other conditions, or their similarity to ambient desiccation browning.

Browning is commonly attributed to degradation of the anthocyanin pigments by polyphenol oxidase (PPO) activity (Akamine, 1960). However, it is not clear whether the by-products of this degradation contribute to tissue browning. This study was undertaken to understand lychee pericarp browning resulting from heat stress. Emphasis was given to injury localization to determine similarities between heat- and ambient desiccation-induced pericarp browning.

Received for publication 6 July 1992. Accepted for publication 18 Dec. 1992. We acknowledge the financial support provided by the Rural Industries Research and Development Corp. and the Australian Centre for International Agricultural Research. Technical advice given by David Simons, The Univ. of Queensland, Gatton College, is also acknowledged. The cost of publishing this paper was defrayed in part by the payment of page charges. Under postal regulations, this paper therefore must be hereby marked advertisement solely to indicate this fact.

'Dept. of Botany, The Univ. of Queensland, Queensland 4072, Australia.
Litchi chinensis cv. Kwai May Pink syn. Gui Wei were obtained from a commercial orchard in southeastern Queensland (lat. $27^{\circ} \mathrm{S}$ ), Fruit were immersed in hot water $(60 \mathrm{C})$ for 10 $\mathrm{min}$, then kept at $25 \mathrm{C}$ for progressive assessment. We used 60C because it was known to cause rapid browning (Wong et al., 1991). To minimize further changes during sample preparation, fruit were placed in an ice slurry.

Polyphenol oxidase activity was measured polarographically using a method modified from Tremolieres and Bieth (1984) and Wesche-Ebeling and Montgomery (1990). Pericarp tissue was sliced finely, divided into three replicates of $4 \mathrm{~g}$ each, and stored overnight in liquid N. Samples were ground in liquid $\mathrm{N}$ and homogenized with $25 \mathrm{ml} 0.02 \mathrm{M}$ sodium phosphate buffer ( $\mathrm{pH}$ 6.8) containing
$1 \%$ triton $\mathrm{X}-100(\mathrm{v} / \mathrm{v})$ and $1 \%$ polyvinyl pyrrolidone- $40(\mathrm{w} / \mathrm{v})$. The suspension was centrifuged at $20,000 \times g$ for $20 \mathrm{~min}$ at $4 \mathrm{C}$, and the supernatant solution used as the crude enzyme extract. Oxygen consumption was measured with a Clarke $\mathrm{O}_{2}$ electrode (Rank Brothers, Bottisham, U.K.) at 28C. Prewarmed, $2.4 \mathrm{ml}$ of sodium phosphate buffer ( $\mathrm{pH}$ 6.8) and 0.2 $\mathrm{ml}$ of pericarp extract were added to the reaction chamber. Once equilibrium was achieved, $0.4 \mathrm{ml}$ of $0.04 \mathrm{M} 4$-methyl catechol in $0.02 \mathrm{M}$ sodium phosphate buffer ( $\mathrm{pH}$ 6.8) was added, and the rate of $\mathrm{O}_{2}$ consumption recorded.

Anthocyanin concentration was determined using $1 \mathrm{~g}$ of pericarp tissue from each of five fruit and homogenized for $2 \mathrm{~h}$ in $50 \mathrm{ml}$ methanol containing $1 \% \mathrm{HCl}(\mathrm{v} / \mathrm{v})$. The extract was filtered, diluted, and absorbance was determined at $530 \mathrm{~nm}$. Anthocyanin concentration was then calculated according to Fuleki and Francis (1968).

The anatomy of the pericarp was examined before and after heat treatment. Tissue was hand-sectioned, mounted unstained in $30 \%$ glycerol, and observed using an Olympus (Japan) BH02 light microscope. As controls, lychee fruit were also kept for 3 days at 26C and $60 \%$ relative humidity $(\mathrm{RH})$ to induce postharvest ambient desiccation browning.

PPO activity of the pericarp increased immediately after heat treatment (Fig. 1), which corresponded to a rapid browning of the pericarp. Where browning has been studied in other fruit, discoloration correlates well with PPO activity and phenolic concentration (Coseteng and Lee, 1987; Martinez-Cayuela et al., 1988). Consequently, resulting brown pigmentation has been attributed directly to PPO action.

Heat treatment caused brown pigmentation throughout the pericarp (Fig. 2, top). This uniform distribution indicates that PPO was not restricted to specific zones within the pericarp. Under ambient desiccation conditions,

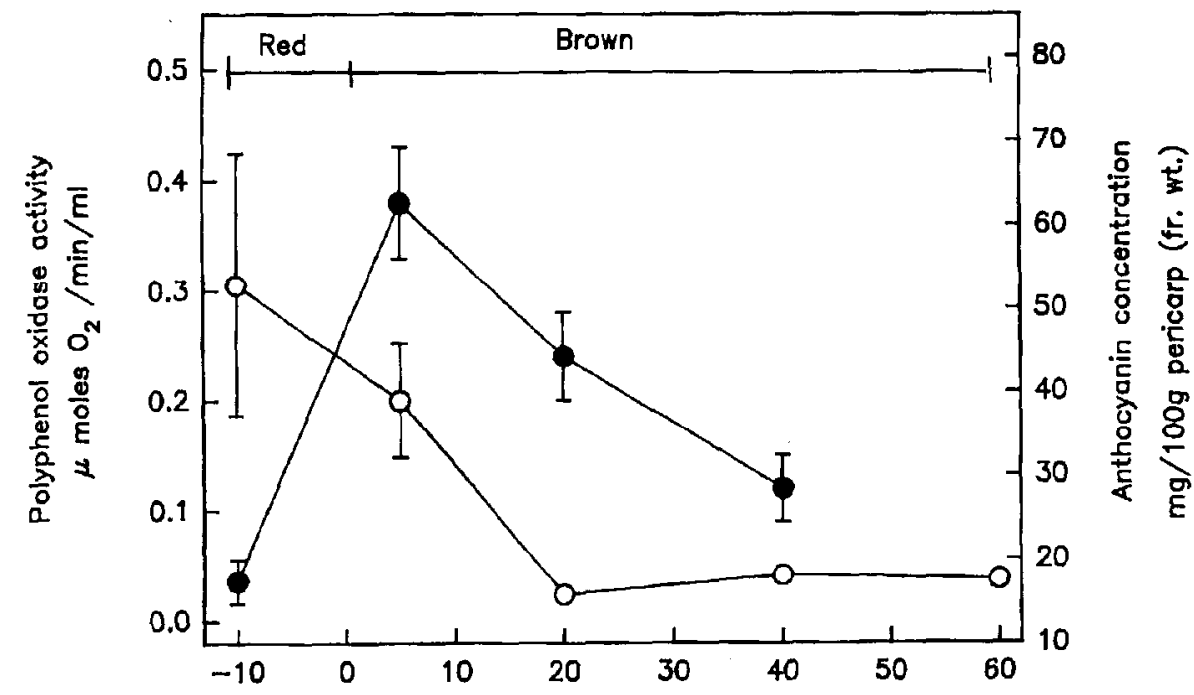

Time ofter heating ( $\mathrm{min}$ )

Fig. 1. Polyphenol oxidase activity $(-0)$ measured polarographically and total anthocyanin concentration $(\mathrm{O}-\mathrm{O})$ of mature lychee pericarp, heat-treated at $60 \mathrm{C}$ for $10 \mathrm{~min}$, as a function of time at $25 \mathrm{C}$. Each point represents the mean of three independent extractions, $\pm \mathrm{SE}$. 


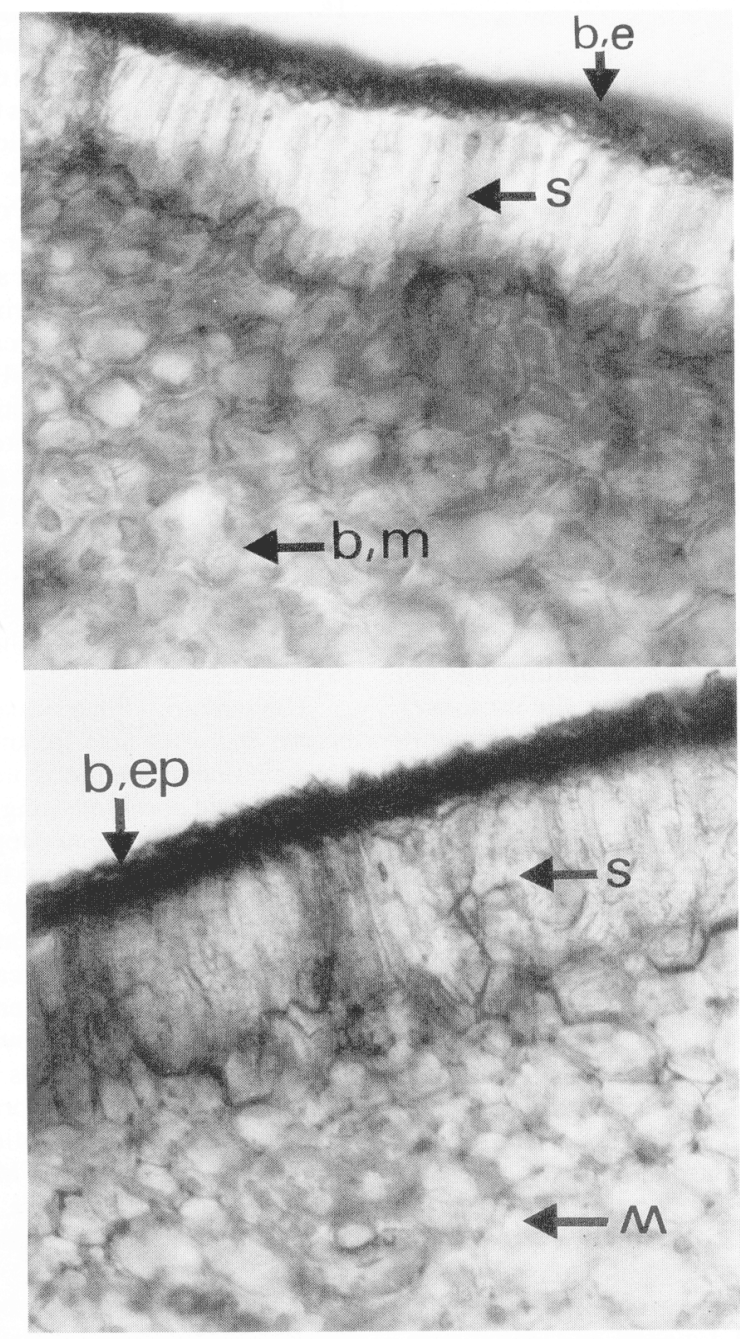

Fig. 2. Cross-sectional view of the lychee pericarp illustrating the distribution of brown pigmentation [tissue browning (b), epicarp (ep), sclerenchyma (s), mesocarp (m)], $\times 50$. (top) Browning resulting from heat treatment at $60 \mathrm{C}$ for $10 \mathrm{~min}$. Section taken after $5 \mathrm{~min}$ at $25 \mathrm{C}$. (bottom) Browning resulting from ambient pericarp desiccation. Section taken after 3 days at $26 \mathrm{C}$, relative humidity $60 \%$.

however, resulting tissue browning was highly localized, with brown pigmentation restricted to the epicarp zone (Fig. 2, bottom). Further desiccation had little effect on distribution, and it is unlikely that this simply represents a difference in stress severity. Although both heat- and desiccation-induced pericarp browning were similar visually, the anatomical distribution of brown pigmentation was distinct. Whether this reflects a difference in the localization of PPO activity or the presence of other browning enzymes, such as peroxidase, needs to be established. Although peroxidase is not considered to play a major role in ambient desiccation browning (Zauberman et al., 1991), this does not preclude a possible role in heatinduced browning.

Anthocyanin concentration decreased after heating, and little pigment remained after 20 min (Fig. 1). Based on previous thermal stability studies (Meschter, 1953), heat treatment at 60C for 10 min would result in little thermal decomposition of anthocyanin over $60 \mathrm{~min}$. Anthocyanin degradation is therefore likely to occur as a consequence of PPO activity. However, multiple degradation pathways are known to exist, with accelerated decomposition also facilitated by other cellular constituents, such as sugar derivatives and ascorbic acid (Markakis, 1982).

Although anthocyanin degradation occurred concomitant with tissue discoloration, there is little consistent evidence to support a relationship between anthocyanin degradation products and the development of brown pigmentation. In fresh tissue, the anthocyanin pigments were restricted to the mid-to upper mesocarp and epicarp region (Underhill and Critchley, 1993). Following ambient desiccation, browning only occurred in the epicarp zone with no discoloration in the mesocarp, even though this zone represented the greatest concentration of anthocyanins. Similarly, browning subsequent to heat injury occurred uniformly throughout the pericarp, independent of initial anthocyanin localization. Although diffusion throughout the pericarp resulting from heat-induced cellular disruption may contribute to this uniform browning response, it would not explain the highly localized nature of ambient browning. We believe that although PPO activity maybe responsible for anthocyanin degradation, tissue browning is likely to result from nonselective degradation of a range of cellular products.

Although the injury caused by both heat and ambient desiccation is similar in appearance, distinct anatomical differences exist in the distribution of brown pigmentation. Further work is required to understand the mechanisms of injury in lychee pericarp browning.

\section{Literature Cited}

Akamine, E.K. 1960. Preventing the darkening of fresh lychees prepared for export. Hawaii Agr. College Expt. Sta. Tech. Rpt. 127.

Coseteng, M.Y. and C.Y. Lee. 1987. Changes in apple polyphenoloxidase and polyphenol concentrations in relation to the degree of browning. J. Food Sci. 52:985-989.

Fuleki, T. and F.J. Francis. 1968. Quantitative methods for anthocyanin. 1. Extraction and determination of total anthocyanin in cranberries. J. Food Sci. 33:72-77.

Huang, S., H. Hart, H. Lee, and L. Wicker. 1990. Enzymatic and color changes during post-harvest storage of lychee fruit. J. Food Sci. 55:17621763 .

Huang, P.Y. and K.J. Scott. 1985. Control of rotting and browning of litchi fruit after harvest at ambient temperatures in China. Trop. Agr. 62:2-4.

Markakis, P. 1982. Stability of anthocyanin in foods, p. 163-178. In: P. Markakis (ed.). Anthocyanin as food colors. Academic, New York.

Martinez-Cayuela, M., S. Sanchez de Medina, M.J. Faus, and A. Gill. 1988. Cherimoya (Annona cherimola Mill) polyphenoloxidase: Monophenolase and dihydroxyphenolase activities. J. Food Sci. 53:1191-1194.

Meschter, E.L. 1953. Effects of carbohydrates and other factors on strawberry products. J. Agr. Food Chem. 1:574-579.

Nip, W. 1988. Handling and preservation of lychee (Litchi chinensis Sonn) with emphasis on colour retention. Trop. Sci. 28:5-11.

Scott, K.J., B.I. Brown, G.R. Chaplin, M.E. Wilcox, and J.M. Bain. 1982. The control of rotting and browning of litchi fruit by hot benomyl and plastic films. Scientia Hort. 16:253-262.

Sharma, S.B., P.K. Ray, and R. Rai. 1986. The use of growth regulators for early ripening of litchi (Litchi chinensis Sonn). J. Hort. Sci. 61:533534.

Tremolieres, M. and J.G. Bieth. 1984. Isolation and characterization of polyphenoloxidase from senescent leaves of black poplar. Photochemistry 23:501-505.

Underhill, S.J.R. and C. Critchley. 1993. Physiological, biochemical and anatomical changes in lychee (Litchi chinensis Sonn.) pericarp during storage. J. Hort. Sci. 68(2): In press.

Wesche-Ebeling, P. and M.W. Montgomery. 1990. Strawberry polyphenol oxidase: Extraction and partial characterization. J. Food Sci. 55:13201324.

Wong, L.S., K.K. Jacobi, and J.E. Gales. 1991. The influence of hot benomyl dips on the appearance of cool stored lychee (Litchi chinensis Sonn.). Scientia Hort. 46:245-251.

Zauberman, G., R. Roren, M. Akerman, A. Weksler, I. Rot, and Y. Fuchs. 1991. Post-harvest retention of the red colour of litchi fruit pericarp. Scientia Hort. 47:89-97. 